\title{
Sprawozdanie z panelu dyskusyjnego poświęconego 50 rocznicy wydarzeń Marca 1968 r. w Polsce i w Lodzi, Lódź, 8 marca 2018 r.
}

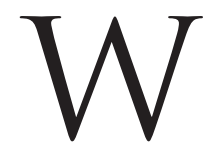
dniu 8 marca 2018 r. w Instytucie Historii Uniwersytetu Łódzkiego (UŁ) odbył się panel dyskusyjny poświęcony wydarzeniom Marca '68 w Polsce i w Łodzi. W 50 rocznicę tegoż jakże przełomowego dla powojennej Polski wydarzenia, gdy na skutek fali czystek antysemickich w partii i wojsku, a także protestów studenckich kraj musiało opuścić blisko 20 tysięcy obywateli polskich pochodzenia żydowskiego, w gronie ekspertów omawiano przyczyny, przebieg wydarzeń i ich skutki, głównie dla Łodzi i regionu łódzkiego. Dyskusja toczyła się w następującym składzie: dr Rafał Ossowski z łódzkiego oddziału Instytutu Pamięci Narodowej, prof. UŁ dr hab. Przemysław Waingertner z Katedry Historii Najnowszej Polski (który był jednocześnie przewodniczącym i moderatorem debaty), a także prof. UŁ dr hab. Krzysztof Lesiakowski, znawca dziejów Polski w latach 1944-1989. Wydarzenie to zebrało bardzo liczna publiczność - nie tylko studentów historii, lecz także uczniów XXIX Liceum Ogólnokształcącego im. Jana „Rudego” Bytnara w Łodzi, jak również samych uczestników wypadków marcowych w Łodzi.

Wymiana poglądów i zdań między uczestnikami panelu była bardzo ożywiona i ciekawa, m.in. dr Ossowski przedstawił kulisy antyżydowskich posunięć w Komitecie Wojewódzkim Polskiej Zjednoczonej Partii Robotniczej w Łodzi i przebieg protestów studenckich na UŁ. Profesor K. Lesiakowski natomiast ukazał proces usuwania oficerów pochodzenia żydowskiego z łódzkiego garnizonu Ludowego Wojska Polskiego i lekarzy z Wojskowej Akademii Medycznej. Z kolei prof. P. Waingertner zaakcentował udział Milicji Obywatelskiej (MO) i Ochotniczej Rezerwy Milicji Obywatelskiej (ORMO) w pacyfikowaniu wystąpień studenckich. W ostatecznych 
konkluzjach wysunięto wniosek, że Łódź była jednym z najbardziej aktywnych ośrodków masowych demonstracji studenckich w Polsce, a ich charakter miał burzliwy przebieg.

Po zakończeniu części dyskusyjnej z sali zaczęto zadawać pytania. Uczestnicy spotkania chcieli poznać dokładne liczby usuniętych $z$ armii oficerów pochodzenia żydowskiego, poddanych czystce antysemickiej w środowisku lekarskim i ukaranych przez komunistyczny aparat represji uczestników wystapień studenckich. Pytano się również o to, gdzie były najsilniejsze ośrodki protestacyjne na Uniwersytecie Łódzkim w marcu 1968 r. Na uwagę zasługiwała także relacja prof. Marka Styczyńskiego - jednego $z$ bohaterów i świadków tychże wydarzeń - który przedstawił w sposób bardzo wyrazisty i żywy własne doświadczenia i przeżycia $z$ tamtego czasu, odnosząc je także do sytuacji politycznej Polski po 1989 r.

Podsumowując, panel dyskusyjny o Marcu '68 w Łodzi spotkał się $z$ dużym odbiorem społeczności studenckiej Instytutu Historii UŁ i reszty obserwatorów. Dyskusja była interesujacca, przedstawiając $\mathrm{w}$ sposób przystępny i zrozumiały prawdę o tych wydarzeniach w mieście nad rzeką Łódką.

Maciej Tadeusz Mańkowski UNIWERSYTET ŁÓDZKI*

* Wydział Filozoficzno-Historyczny, Studium Doktoranckie Nauk Humanistycznych, e-mail: aucklandrts@gmail.com. 